\title{
Starch/PVA-based nanocomposites reinforced with bamboo nanofibrils
}

\author{
Mario Guimarães Jr. ${ }^{\mathrm{a}, *}$, Vagner Roberto Botaro ${ }^{\mathrm{b}}$, Kátia Monteiro Novack ${ }^{\mathrm{c}}$, \\ Fábio Gomes Teixeira ${ }^{\mathrm{d}}$, Gustavo Henrique Denzin Tonoli ${ }^{\mathrm{e}}$ \\ a Departamento de Eletromecânica - Centro Federal de Educação Tecnológica de Minas Gerais, Araxá, Doctoral Candidate in Materials Engineering for \\ REDEMAT/UFOP, Av. Ministro Olavo Drummond, 25, São Geraldo, Araxá, MG CEP 38180-510, Brazil \\ ${ }^{\mathrm{b}}$ Departamento de Pós-Graduação em Ciência dos Materiais - Universidade Federal de São Carlos, Sorocaba, Cx.P 3031, Sorocaba, SP CEP 18052-780, Brazil \\ ' Instituto de Ciências Exatas e Biológicas/Departamento de Química-Universidade Federal de Ouro Preto, Ouro Preto, MG, Campus Universitário, morro do \\ Cruzeiro, CEP 35400-000, Brazil \\ d Instituto de Tecnologia de Alimentos, Centro de Tecnologia de Embalagem (ITAL/CETEA), Avenida Brasil, 2880, Campinas, SP CEP 13070-178, Brazil \\ e Departamento de Ciências Florestais, Universidade Federal de Lavras, Cx P. 3037, Lavras, MG CEP 37200-000, Brazil
}

\section{A R T I C L E I N F O}

\section{Article history:}

Received 29 October 2014

Received in revised form 12 February 2015

Accepted 7 March 2015

Available online 19 March 2015

\section{Keywords:}

Nanofibrils

Bionanocomposite

Bamboo pulp

Mechanical defibrillation

\begin{abstract}
A B S T R A C T
This work aimed to evaluate the effect of including different concentrations of bamboo nanofibrils on physical, mechanical, morphological and structural properties of nanocomposites from cassava starch and polyvinyl alcohol (PVA). Nanocomposites were prepared with blends of starch/PVA and nanofibrils of bamboo. Chemical pre-treatments and mechanical defibrillation were used to obtain the nanofibrils. The mixture containing $3 \%$ of starch and $4 \%$ of PVA in the proportion of $20 / 80$ (starch/PVA) were chosen after preliminary testing. Atomic force microscopy (AFM) and transmission electronic microscopy (TEM) were used to characterize the bamboo nanofibrils. Microstructure of the nanocomposites was evaluated using scanning electron microscopy (SEM) and X-ray diffractrometry (XRD). Physical and mechanical properties were also evaluated. Results showed that pre-chemical treatments increased the content of the alpha-cellulose in bleached pulp by approximately $112 \%$ in relation to the native fiber. Increasing the number of passages through the defibrillator reduced the average diameter of the bamboo nanofibrils (from $82 \pm 29 \mathrm{~nm}$ to $10 \pm 6 \mathrm{~nm}$ ). Addition of $6.5 \%$ nanofibrils improved the tensile strength and elongation at the break of the nanocomposite by 24 and 51\%, respectively, but reduced the tensile modulus by $40 \%$ in relation to control (unreinforced) blend. Nanofibrils decreased the transparency of the nanocomposite films. The water vapor permeability and water solubility of the nanocomposite containing high contents of nanofibrils decreased up to $20 \%$ and $30 \%$, respectively, in relation to the control blend.
\end{abstract}

(c) 2015 Elsevier B.V. All rights reserved.

\section{Introduction}

Ecological concern has increased the interest on natural and renewable materials, making plant fibers and biodegradable polymers an interesting and secure alternative for development of new materials. Most common biodegradable polymers are obtained from polysaccharides and polyesters. Between the polysaccharides, thermoplastic starch (TPS) has been largely used, despite presenting some disadvantages, such as strong hydrophilicity, poor mechanical properties in comparison to conventional polymers and variations of post-processing properties. Some strategies have been presented to improve these properties, including the use

\footnotetext{
* Corresponding author. Tel.: +55 3436694500.

E-mail address: mgjunior@araxa.cefetmg.br (M. Guimarães Jr.).
}

of blending (Mohanty et al., 2000; Averous and Boquillon, 2004; Olobarrieta, 2005).

Several studies have examined blending starch with other polymers due to the relative facility of obtaining materials with desirable properties with no need to significant changes or investments on the conventional process. Thus, polymeric blends are a versatile technological solution to obtain polymeric materials with myriad specifications at relatively low cost using combinations of polymers with properties of interest (Utracki, 1989; Ishiaku et al., 2002). Many types of biodegradable PVA-based composites have been prepared through mixture with starch (Follain et al., 2005; Lawton, 1996; Siddaramaiah et al., 2004; Cinelli et al., 2006; Zhai et al., 2003; Khan et al., 2006). Chemical modification, including cross linking with glutaraldehyde and epichlorohydrin, has also been used by several authors to improve the physical properties 

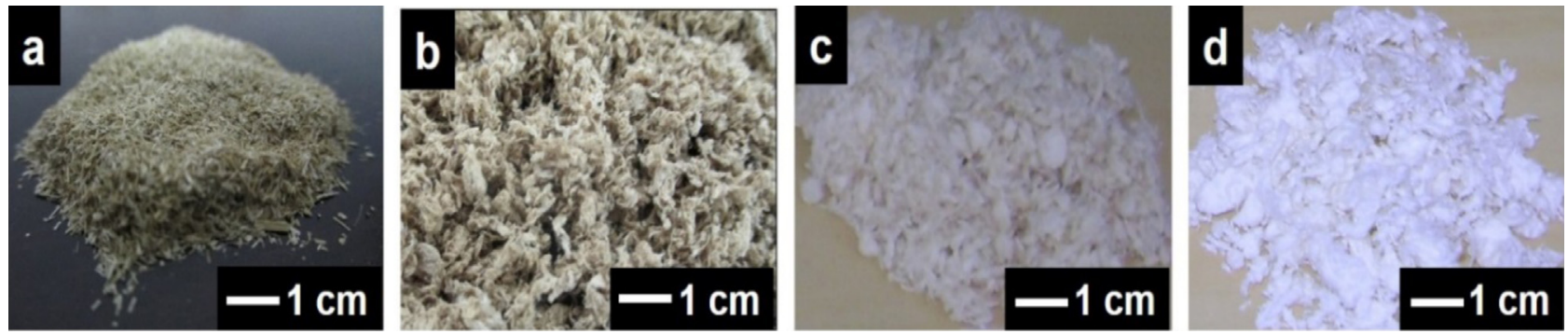

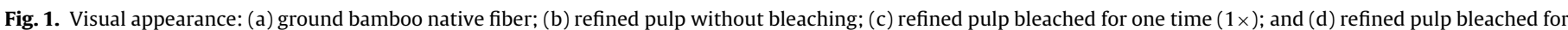
two times $(2 \times)$.

and limitations of these polymers (Nabar et al., 2006; Beliakova et al., 2004; Ramaraj, 2007; Sreedhar et al., 2006).

In recent years, nanofibrils and nanocrystals obtained from plant fibers have been studied as reinforcement in starch-based nanocomposites. The use of these two types of cellulosic nanoreinforcements in polysaccharides matrices has increased because of their great affinity. Large specific surface area, high aspect ratio and high capacity to form structured nets make cellulosic nanofibrils excellent low-cost and non-toxic reinforcement agents (Chang et al., 2010; Chang et al., 2010). This class of materials presents micrometric lengths and nanometric widths, leading to interest potential for several applications, including drugs (Villanova et al., 2011), dietary food (Okiyama et al., 1993), special papers (Nguyen and Tan, 2009), reinforcement in packaging/films (Siro and Plackett, 2010; Syverud et al., 2011) and polymeric matrices (Orts et al., 2005; Azizi Samir et al., 2005; Siqueira et al., 2010).

The present work aimed to evaluate the effect of including various concentrations of bamboo nanofibrils on mechanical, morphological, structural and physical properties of cassava starch/PVA-based nanocomposites.

\section{Materials and methods}

\subsection{Materials}

Commercial unbleached refined bamboo cellulose pulps from Bambusa Vulgaris Schrad (around 2 years of age), were obtained from CEPASA - Celulose e Papel de Pernambuco S/A, Jaboatão dos Guararapes, Brazil. The bamboo pulp was produced by the sodaanthraquinone process ( $\mathrm{NaOH}-\mathrm{AQ}$ ), with approximately, $18 \% \mathrm{NaOH}$ and $0.03 \%$ anthraquinone $\left(\mathrm{C}_{14} \mathrm{H}_{8} \mathrm{O}_{2}\right)$ per unit of solid mass, $\mathrm{pH}$ between 12 and 13, and with a fiber yield estimated in 46\%. After batching in a Pandia continuous digester at $6-7$ bar and $170^{\circ} \mathrm{C}$ for $45 \mathrm{~min}$, samples were disk refined until a Schopper Riegler (SR) index of around 25-30.

Composite matrix was formed by: modified cassava starch FMM (Cargill, lot 1,209,035, type A), crystallinity index (CI) of around $45 \%$ and amylopectin content of $85 \%$; polyvinyl alcohol - PVA (Sigma-Aldrich, lot MKBK3473V), with molecular weight (Mw) of $130.000 \mathrm{~g} / \mathrm{mol}, 99 \%$ hydrolyzate; and liquid glycerol (Sigma-Aldrich) as plasticizer agent, with Mw of $92.09 \mathrm{~g} / \mathrm{mol}, \geq$ $99 \%$ concentration and density of $1.26 \mathrm{~g} / \mathrm{mL}$.

\subsection{Pre-treatment and characterization of the bamboo pulp}

Before obtaining bamboo nanofibrils, the refined pulp sample was subjected twice to alkaline treatment as proposed elsewhere (Corradini et al., 2006) followed by bleaching (Pereira et al., 2010) but maintaining the $\mathrm{pH}$ at 11 in order to prevent brightness reversion. Before repeating or starting a new treatment, samples were washed with tap water until the $\mathrm{pH}$ becomes neutral. In order to calculate fiber yield, the samples were oven dried at $60^{\circ} \mathrm{C}$ for $24 \mathrm{~h}$ and weighted before and after each treatment.
Chemical composition of the refined pulps, with and without treatments, was determined. Sample preparation for chemical analysis followed the procedures described in T264 cm-97 (TAPPI, 1999a) and T257 cm-97 (TAPPI, 1999b) standards. The percentage of holocellulose (cellulose + hemicelluloses) was determined as described in T9 m-54 (TAPPI, 1999c). The contents of alphacellulose and lignin (insoluble in acid) were estimated according to T203 cm-99 (TAPPI, 1999d) and T222 cm-88 (TAPPI, 1999e) standards, respectively. The content of hemicelluloses was calculated from the difference between the values of holocellulose and alphacellulose, and the contents of ash and extractives were calculated in accordance with T211 cm-93 (TAPPI, 1999f) and T204cm-97 (TAPPI, 1999g) standards, respectively. The procedure for determining solubility in ethanol-toluene $(1: 2, \mathrm{v} / \mathrm{v})$ was conducted for $6 \mathrm{~h}$ in ethanol/toluene and $4 \mathrm{~h}$ in ethanol. All determinations were performed in triplicate.

After pre-treatment and characterization, the native fiber and refined pulp without bleaching were called FNA and PRST, respectively, and the pulp twice alkaline treated and bleached were called PRM2 and PRM2B2, respectively. Fig. 1a-d show the ground bamboo native fiber, refined pulp without bleaching, refined pulp bleached for one time $(1 \times)$ and refined pulp bleached for two times $(2 \times)$.

\subsection{Production of bamboo nanofibrils}

Bamboo nanofibrils were obtained by mechanical defibrillation of the pre-treated (twice alkaline treated and twice bleached) refined pulp fibers using a Super Masscolloider Masuko Sangyo MKCA6-3 defibrillator at $1500 \mathrm{rpm}$ (Ifuku et al., 2010). Initially, the bamboo pulp was immersed (at $1.2 \% \mathrm{w} / \mathrm{v}$ concentration) in water for $48 \mathrm{~h}$ for hydration to guarantee the swelling of the fiber cell wall. The gap between the silicon carbide stones in the defibrillator was adjusted to $100 \mu \mathrm{m}$ (Nakagaito and Yano, 2004) and suspensions from refined/bleached fibers were fed several times until form a gel, which began to happen after 15 passages through the defibrillator (Bufalino et al., 2014; Guimarães Junior et al., 2015). The number of passages adopted for this study was 5 and 30, and the electric current consumed was kept at 6 A. Sonication was applied after defibrillation, for $30 \mathrm{~min}$, using a Branson sonicator with a $13 \mathrm{~mm}$ tip, at $450 \mathrm{~W}$ ( $25 \%$ amplitude) and $20-25 \mathrm{KHz}$, which led to $840 \mathrm{~J} / \mathrm{mL}$ energy.

The suspensions were called NRB5x and NRB30x for nanofibrils obtained after 5 and 30 passages through the defibrillator, respectively. Fig. 2 shows the steps of production the bamboo nanofibrils from the solution of bleached refined pulp until obtaining the gel after 30 passages through the mechanical defibrillator.

\subsection{Characterization of the bamboo nanofibrils}

Transmission electron microscopy (TEM) was performed in order to evaluate the morphology of bamboo nanofibrils, using a 

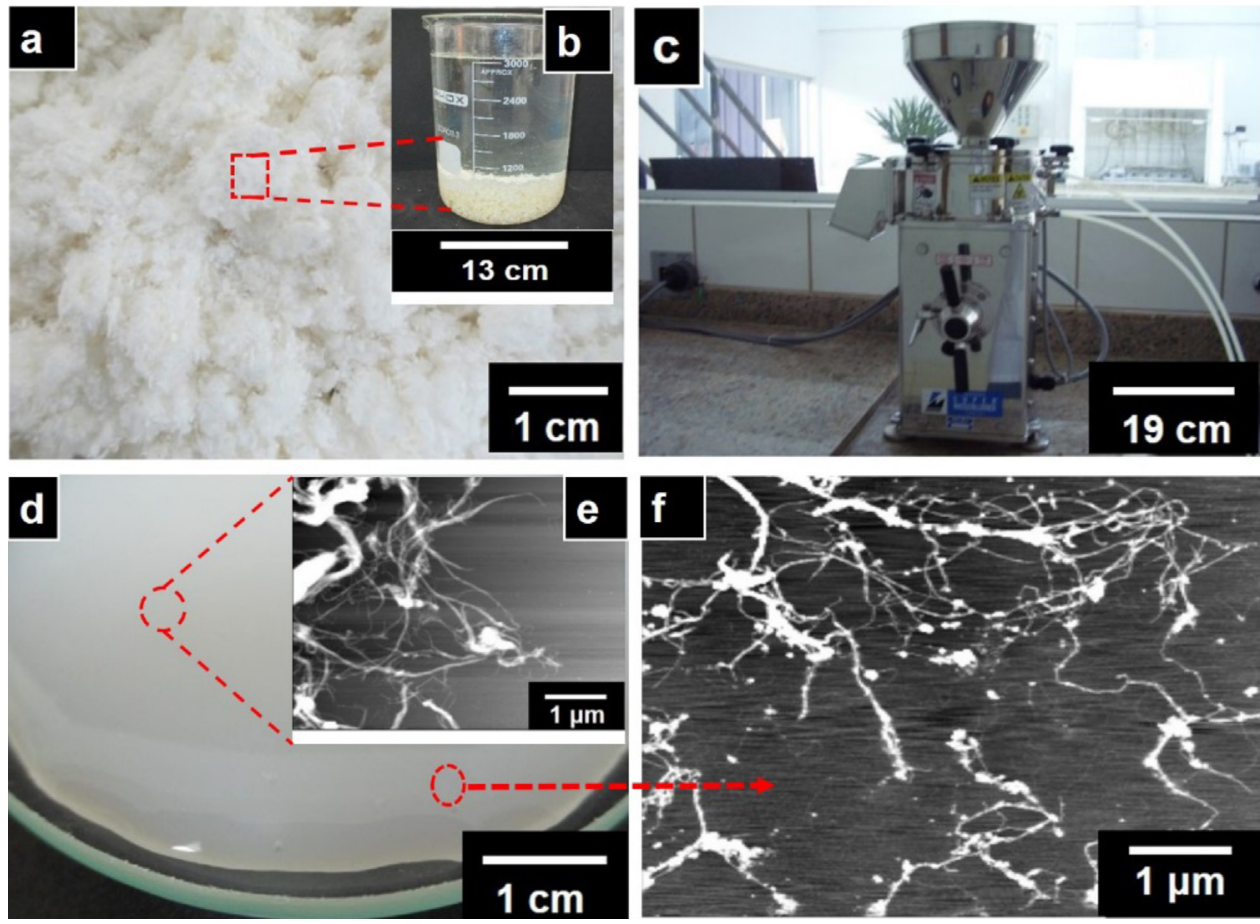

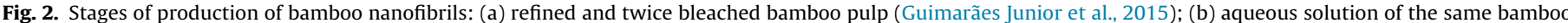

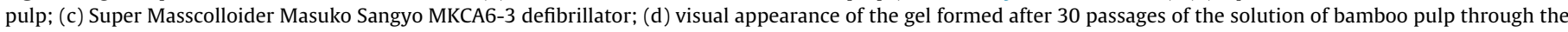
defibrillator (Guimarães Junior et al., 2015); (e) and (f) AFM micrographs of bamboo nanofibrils.

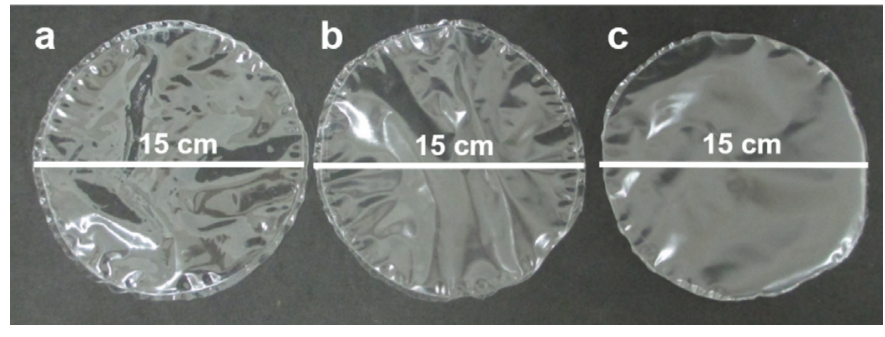

Fig. 3. (a) FMM/PVA blend film (P80/A20); (b) nanocomposite with bamboo nanofibrils (6.5\% dry mass) obtained after 5 passages through the defibrillator; (c) nanocomposite with nanofibrils (6.5\% dry mass) obtained after 30 passages through the defibrillator. Diameter of the films $=15 \mathrm{~cm}$.

Carl Zeiss EM 912 instrument with corrected Omega filter peels, at tension of about $100 \mathrm{kV}$. Aqueous solutions of cellulose nanofibrils $(0.05 \mathrm{~g} / \mathrm{L})$ stained with uranyl acetate were deposited and dried on copper microgrids of 400 mesh. Nanofibril dimensions were measured using the Image J $1.47 \mathrm{~V}$ software. At least 100 measurements were randomly performed to determine the average diameter of the nanofibrils.

Atomic force microscopy (AFM) was performed with an Agilent 5500 N9410S microscope. A drop of a dilute suspension of approximately $0.05 \mathrm{~g} / \mathrm{L}$ was deposited on a cleaved mica surface and dried at $60{ }^{\circ} \mathrm{C}$ for $12 \mathrm{~h}$. The images were obtained in dynamic mode at room temperature with a scan rate of $1 \mathrm{~Hz}$, using silicon tips with a curvature radius of less than $10 \mathrm{~nm}$ and spring constant of $42 \mathrm{~N} / \mathrm{m}$. Image processing and diameter measurements were performed using 64-bit Gwyddion software. The diameters of the nanofibrils were estimated by measuring their heights to eliminate the convolution effect between the probe tip and the bamboo nanofibrils (Kvien et al., 2005). Around 100 nanofibrils were randomly chosen for each condition, and two height measurements were used to determine the average diameter (Silvério et al., 2013). The surface roughness of the mica surface after the deposition of the nanofib- rils was measured in $5 \mu \mathrm{m} \times 5 \mu \mathrm{m}$ scanned areas, using the average surface roughness parameter (Ra in Eq. (1)) of the 64-bit Gwyddion software (Kaboorani and Riedl, 2012). Roughness (Ra) was evaluated in order to estimate how is dispersion of nanofibrils for each number of passages through the defibrillator.

$\mathrm{Ra}=\frac{1}{\mathrm{n}} \sum_{\mathrm{i}=1}^{\mathrm{n}} \mathrm{Zi}-\mathrm{Zm}$,

where:

$\mathrm{Zm}=\frac{1}{\mathrm{n}} \Sigma_{\mathrm{i}=1}^{\mathrm{n}} \mathrm{Zi}$

$\mathrm{Ra}$ (average roughness) is the arithmetic mean of the absolute deviation values from the surface height. $\mathrm{Zm}$ is the average height of the sample points, and $\mathrm{Zi}$ is the height of each sample point. The number of points within each area is represented by $n$.

\subsection{Preparation of the control blend and nanocomposites}

A solution of starch (FMM) was prepared with $3 \%$ starch (FMM), $12 \%$ glycerol and $85 \%$ water. A PVA solution was prepared with $4 \%$ PVA, 25\% glycerol and 71\% water. Both combinations were defined based on previous investigations regarding different proportions of raw materials, and on the ensuing results of water vapor permeability, mechanical and physical properties. For preparing the solutions, both FMM and PVA powders remained immersed for $24 \mathrm{~h}$ in distilled water under mechanical stirring at $100 \mathrm{rpm}$ at room temperature for hydration. Then, glycerol was added and both solutions of FMM and PVA were submitted to magnetic stirring at $500 \mathrm{rpm}$ at 80 and $90^{\circ} \mathrm{C}$, respectively for $20 \mathrm{~min}$. FMM and PVA solutions were mixed in the proportion of 20/80 (FMM/PVA) at room temperature in a homogenizer at $15,000 \mathrm{rpm}$ for $5 \mathrm{~min}$. Around $40 \mathrm{~g}$ of the final solution was poured into Plexiglas acrylic plates $(15 \mathrm{~cm}$ in diameter) for obtaining of the control sample (called P80/A20) by film casting. Finally, it was sonicated and placed in a controlled room at $20^{\circ} \mathrm{C}$ and $60 \%$ relative humidity for 10 days for drying 

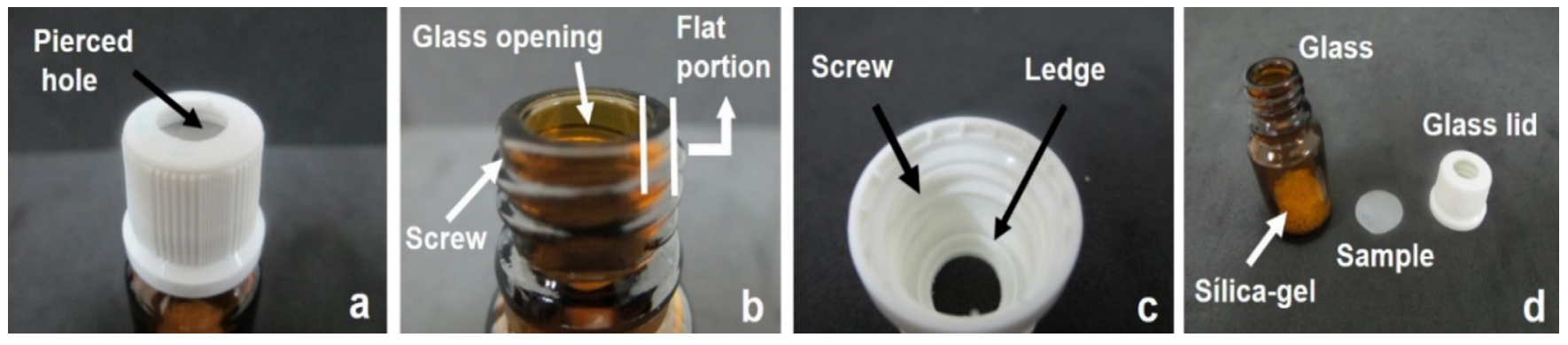

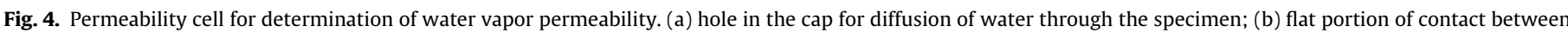

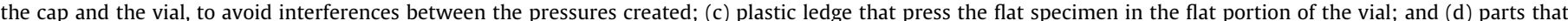
permeability cell.

and moisture stabilization. The thickness of the control blend films varied between 0.064 and $0.093 \mathrm{~mm}$.

The nanocomposites were also prepared by film casting with the blends of starch (FMM) and PVA at 20/80 (FMM/PVA) ratio and reinforced with four different contents $(0.5,1.5,4.5$ and $6.5 \%$ in relation to total solid mass of the film) of bamboo nanofibrils obtained with 5 and 30 passages through the defibrillator. The aqueous suspensions of nanofibrils were added to the FMM/PVA blend under mechanical stirring at $750 \mathrm{rpm}$ at room temperature for $15 \mathrm{~min}$, and homogenized at $15,000 \mathrm{rpm}$ at room temperature for $20 \mathrm{~min}$. Then, the blend solutions with nanofibrils were subjected to $1 \mathrm{~h}$ of sonication at $450 \mathrm{~W}$ with $25 \%$ amplitude (energy of around $1.7 \mathrm{KJ} / \mathrm{mL}$ ). Finally, the solutions were poured into Plexiglas acrylic plates and placed in a controlled room at $20^{\circ} \mathrm{C}$ and $60 \%$ relative humidity for 10 days for drying and moisture stabilization. The thickness of the nanocomposite films varied between 0.073 and $0.121 \mathrm{~mm}$. Fig. 3 shows the blend films and flexible nanocomposites obtained.

\subsection{Characterization of the nanocomposites}

\subsubsection{Mechanical properties}

The maximum tensile strength (TS), the elongation at breaking (TB) and the tensile modulus (TM) of nanocomposites were determined in an INSTRON model 5966-E2 instrument with an $1 \mathrm{kN}$ load cell, deflection rate of $50 \mathrm{~mm} / \mathrm{min}$, and initial distance between the clamping jaws of $50 \mathrm{~mm}$. The tensile test was performed following the ASTM D 882-00 standard. Test specimens with $15 \mathrm{~mm}$ width and $100 \mathrm{~mm}$ length were used, and the TM was calculated from the tangent of the initial linear function of the stress- strain curve. Five repetitions were used for each percentage of bamboo nanofibrils tested.

\subsubsection{Scanning electron microscopy (SEM)}

A Shimadzu SSX-550 scanning electron microscope (SEM) operating in a high vacuum chamber at acceleration voltage of $15 \mathrm{kV}$ was used to analyze the surface morphology of the blend and nanocomposite films. A secondary electron detector was used to capture the images. A nanolayer of gold particles was deposited on the film surfaces for $2 \mathrm{~min}$ at $330 \mathrm{~V}$ and $20 \mathrm{~mA}$ in a physical vapor depositor (PVD).

\subsubsection{X-ray diffractometry (XRD)}

The crystallinity index of the nanocomposites were estimated from X-ray diffraction using a Shimadz XRD- 6000 diffractometer at room temperature, step size of $0.05^{\circ}$ and an integration time of $1 \mathrm{~s}$. The radiation used was $\mathrm{CuK} \alpha(1.5406 \AA)$, which was generated by $40 \mathrm{kV}$ and an incident current of $30 \mathrm{~mA}$. Flat pieces of nanocomposites were cut and fixed in the glass sample holder. Crystallinity index was calculated by deconvolution of the diffraction peaks using a Lorentzian function of the crystalline and amorphous peaks
(Chen et al., 1999). A Savitzky-Golay filter was used to smooth the curves.

\subsubsection{Physical properties}

2.6.4.1. Optical transmittance (Tr). The transmission of light through the nanocomposites was measured in a Shimadzu UV-vis 1601 spectrophotometer, with a double-beam tungsten lamp, accuracy of $0.5 \mathrm{~nm}$ and a spectral band of $2 \mathrm{~nm}$. This technique allowed the evaluation of the total percentage of incident light that is transmitted through the nanocomposites before and after the incorporation of bamboo nanofibrils. The scan was performed between 400 and $800 \mathrm{~nm}$, and transparency was evaluated according to procedures described elsewhere, (Kampeerapappun et al., 2007; Chen et al., 2008). Specimens were cut into rectangles with $10 \mathrm{~mm} \times 50 \mathrm{~mm}$ and adhered to the internal wall of the quartz cuvette of the spectrophotometer (Park and Zhao, 2004). Three repetitions were performed for each nanofibril content. The empty quartz cuvette was used as the totally transparent control. The device was programmed to display the light transmittance value (\%) passed through the nanocomposites.

2.6.4.2. Water vapor permeability (WVP). The water vapor transmission rate (WVTR) of the blend and nanocomposites was determined by gravimetry using the ASTM E 96-00 standard. The test specimens were cut with a radius of $5.25 \mathrm{~mm}$ and placed between the cap and the amber glass vials of the permeability cell (Fig. 4) with $3 / 4$ of its volume containing $\mathrm{CaCl}_{2}$ (desiccant) previously dried. Then, the amber glass was placed in hermetic desiccators at $18.5 \pm 2{ }^{\circ} \mathrm{C}$, whose a volume of water sets the water activity to 0.1 in contact with the upper face of the specimen. The weight gain was measured each $24 \mathrm{~h}$ until 10 days of moisture exposure. A plot of weight gain versus time was used to determine the WVTR. The slope of the linear portion of this plot represents the steady state amount of water vapor diffusing through the specimen. Three repetitions were performed for blend and each nanofibril content. The water vapor permeability (WVP) was calculated by multiplying the steady WVTR by the specimen thickness $(\mathrm{mm})$ and dividing that by the water vapor pressure difference ( $\Delta p=2.1297 \mathrm{kPa}$; Tetens, 1930) across the specimen (Bourtoom and Chinnan, 2008). Fig. 4 shows details of the permeability cell.

2.6.4.3. Solubility. Water solubility was determined using circular test specimens of $3.14 \mathrm{~cm}^{2}$. The initial dry mass was obtained after drying at $55 \pm 2{ }^{\circ} \mathrm{C}$ for $24 \mathrm{~h}$. Specimens were immersed in a vessel containing $30 \mathrm{~mL}$ of distilled water and magnetic stirred at $50 \mathrm{rpm}$ for $24 \mathrm{~h}$ at room temperature. The resultant suspensions were filtered, and the residues were dried at $105^{\circ} \mathrm{C}$ for $24 \mathrm{~h}$. After weighing, the amount of non-solubilized material was determined. The solubility of the specimens was expressed as percentage of mass solubilized in relation to the initial mass (Gontard et al., 1994). 

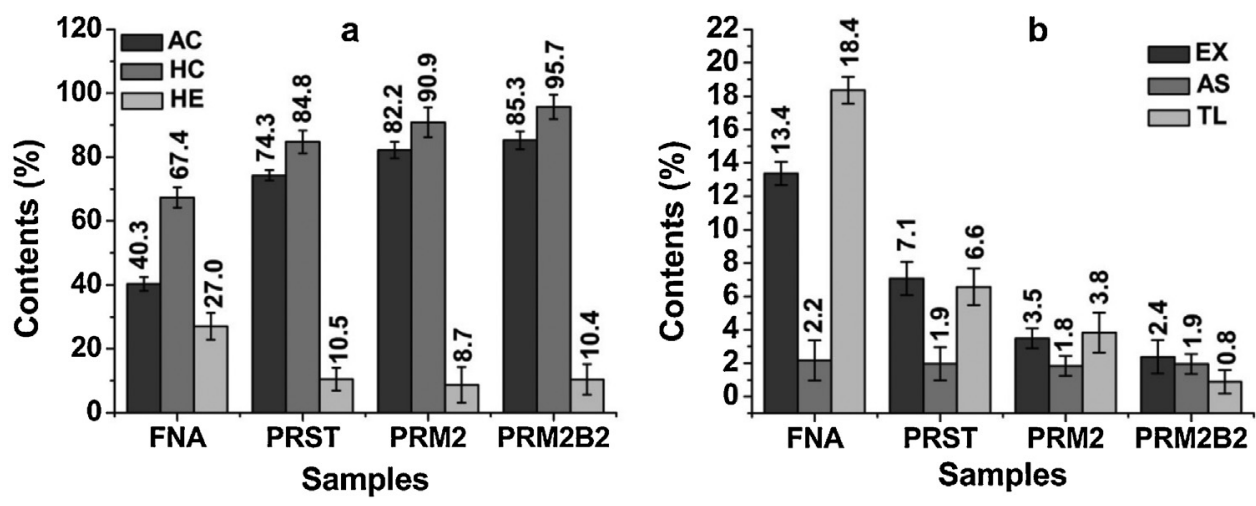

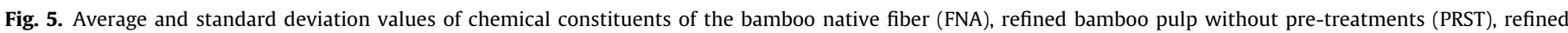

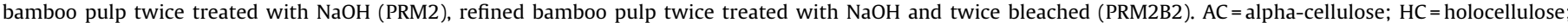
$\mathrm{HE}=$ hemicellulose; $\mathrm{EX}=$ extractives; $\mathrm{AS}=$ ashes; and $\mathrm{TL}=$ total lignin.

\subsubsection{Statistical analysis}

Sisvar 5.0 was used for carrying out statistical analyzes of data through average comparison. Fisher's least significant difference and Scott-Knott test were used at 95\% confidence level for mechanical and physicals properties.

\section{Results and discussion}

\subsection{Characterization of the native fiber and bamboo pulp}

Lignin and hemicelluloses removal from surrounding the cellulose micro/nanofibrils of the plant cell wall is one of the most important steps for obtaining cellulose nanofibrils, since lignin and hemicelluloses act as binders in the fibrillar structure, preventing their individualization (Nakagaito and Yano, 2004; Dufresne et al., 1997; Dinand et al., 1999). Purely mechanical processes can cause excessive cellulose fibril breaking and incur an increase in energy consumption (Siro and Plackett, 2010). The combination of both chemical and mechanical methods can lead to nanofibrils with excellent quality and with low energy consumption.

Fig. 5 presents the chemical constitution of the fibers after the pre-treatments. The native bamboo fiber (FNA) presented lower percentages of alpha-cellulose $(A C=40.3 \%)$ and holocellulose $(\mathrm{HC}=67.4 \%)$, and higher percentages of hemicelluloses $(\mathrm{HC}=27.0 \%)$, total lignin $(\mathrm{TL}=18.4 \%)$, extractives $(\mathrm{EX}=13.4 \%)$ and ash $(A S=2.2 \%)$ compared to the pre-treated pulps. After pulping with $\mathrm{NaOH}-\mathrm{AQ}$ (sodium hydroxide + anthraquinone) followed by refining (PRST), the content of alpha-cellulose (AC) and holocellulose $(\mathrm{HC})$ of the pulp increased significantly to $74.3 \%$ and $84.8 \%$, respectively, while the content of hemicelluloses (HE), total lignin (TL) and extractives (EX) decreased to $10.5,6.6$ and $7.1 \%$, respectively. Results agree with values found in literature for the same studied species (Gomide et al., 1982; Morais et al., 2000; Gomide, 1986) and within the range for other bamboo species with age between 2 and 4 years (Mwaikambo, 2006; Li et al., 2007; Wahab et al., 2013).

After the second bleaching (PRM2B2), there was an increase of 111.7 and $42.0 \%$ in the content of $\mathrm{AC}$ and $\mathrm{HC}$, while values of $\mathrm{HE}, \mathrm{TL}$ and EX reduced by $61.5,96.0$ and $82.1 \%$, respectively in relation to natural fiber (FNA). The high content of AC and $\mathrm{HC}$ after pre-treatment indicate the opening of the lignocellulosic structure of the fibers, causing hydrolysis of the hemicelluloses and cleavage of lignin-hemicelluloses bonds, which resulted in removal of hemicelluloses and almost all the lignin of the pulp (Suess, 2010).

\subsection{Characterization of the bamboo nanofibrils}

\subsubsection{Morphological analyses}

Fig. 6a and b depicts AFM images of the bamboo nanofibrils obtained after 5 and 30 passages through the defibrillator, respectively. The mechanical disruption caused by defibrillation resulted in fibrillar structures with lengths estimated on tens of micrometers and diameters predominantly smaller than $100 \mathrm{~nm}$ (Fig. 6c and $d$ ). The reduction of the average diameter with the increase of number of passages (i.e., from 5 to 30 ) was of around $88 \%$. The diameters changed from $82 \pm 29 \mathrm{~nm}$ to $10 \pm 6 \mathrm{~nm}$, turning the nanofibril suspensions more stable for the sample with 30 passages through the defibrillator. Furthermore, the suspension with 30 passages presented $66 \%$ of nanofibrils with diameter between 5 and $15 \mathrm{~nm}$ (Fig. 6d), while 5 passages let to around $37 \%$ of nanofibrils in the same range (Fig. 6a). The analysis of roughness ( $\mathrm{Ra}$ ) of the surface after nanofibril deposition showed high values of Ra for samples obtained with 5 passages, which is evidence of low quality dispersion of nanofibrils, and indicates the presence of nanofibril clusters (Kaboorani and Riedl, 2012).

Fig. 7a and b show TEM images of bamboo nanofibrils after 5 and 30 passages through the defibrillator. Again, it is observed that 30 passages (Fig. 7b) improved the individualization of the nanofibrils in relation to 5 passages (Fig. 7a). Fig. 7c and d present the diameter distribution (measured in the TEM images) of the nanofibrils. The values measured after 5 and 30 passages were $123.1 \pm 14.7 \mathrm{~nm}$ and $19.3 \pm 9.2 \mathrm{~nm}$, respectively, which were higher than those measured in the AFM images. Similar behavior was found in literature (Flauzino Neto et al., 2013). Results of the morphology obtained in the present work are consistent with nanofibers extracted from other sources (Karimi et al., 2014; Chen et al., 2011 Li et al., 2014; Abe and Yano, 2010; Tonoli et al., 2012).

\subsection{Characterization of the nanocomposites}

\subsubsection{Mechanical properties}

Fig. 8 shows the average and standard deviation values of tensile strength, elongation at break and tensile modulus of the blend (P80/A20) and nanocomposites reinforced with different contents of nanofibrils obtained with 5 (Fig. $8 \mathrm{a}-\mathrm{c}$ ) and 30 (Fig. 8d-f) passages through the defibrillator. Tensile strength, elongation at break and tensile modulus of the control blend (P80/A20) were $26.3 \mathrm{MPa}$, $186 \%$ and 503MPa, respectively. No significant $(p \leq 0.05)$ increase in tensile strength was observed for inclusion of bamboo nanofibrils obtained with 5 passages (Fig. 8a). Nanocomposites reinforced with $4.5 \%$ of nanofibrils from 5 passages presented significant $(p \square 0.05$ ) higher values of elongation at break than the other samples, and 


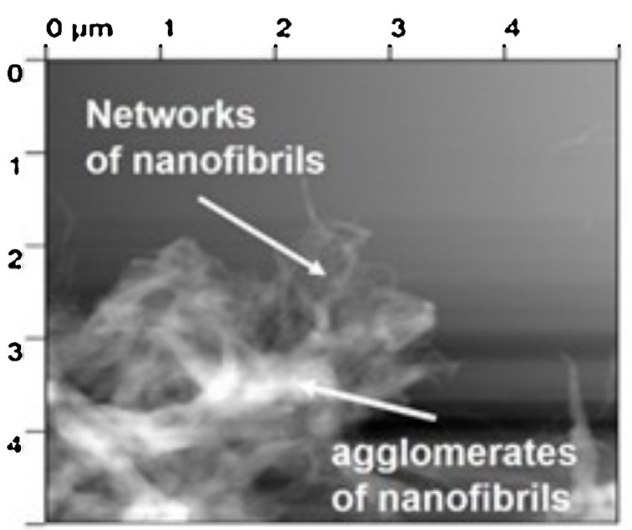

a

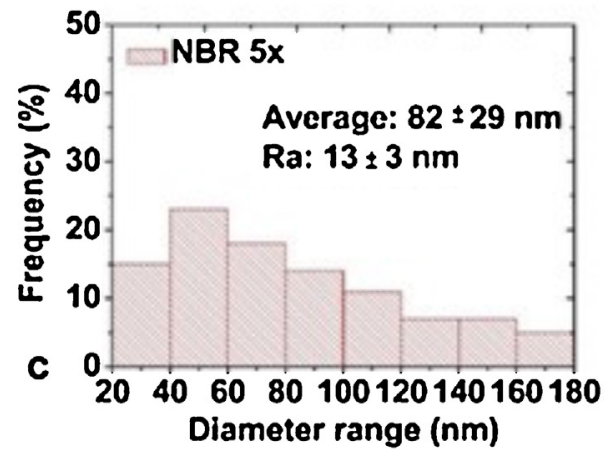

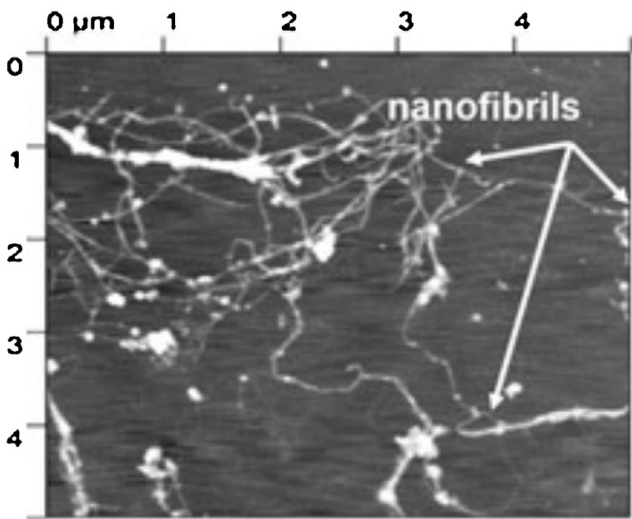

b

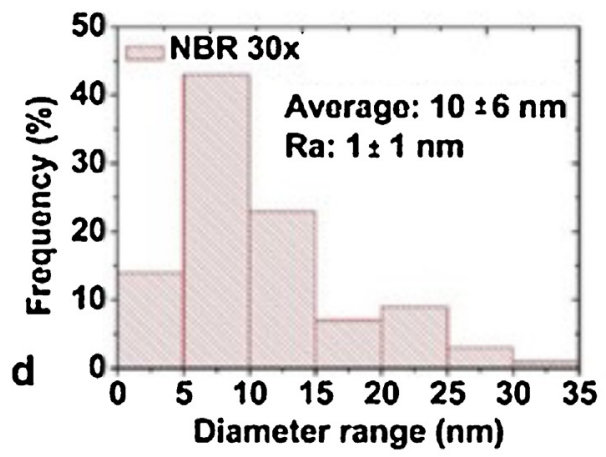

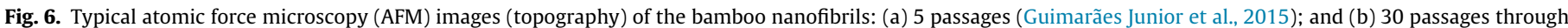

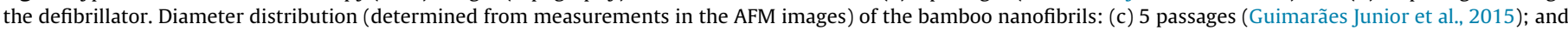

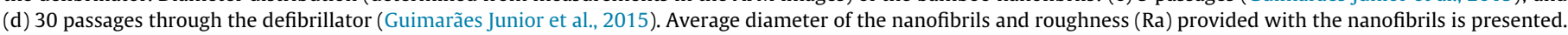
Scanning area was $25 \mu \mathrm{m}^{2}(5 \mu \mathrm{m} \times 5 \mu \mathrm{m})$.

leading to around $29 \%$ more ductile film than the control blend (Fig. 8b). Tensile modulus increased significantly (12\% in relation to the control blend) for nanocomposite with $0.5 \%$ nanofibrils and decreased significantly for nanocomposites with $4.5 \%$ and $6.5 \%$ of nanofibrils (Fig. 8c).

The addition of 4.5 and $6.5 \%$ of bamboo nanofibrils obtained with 30 passages resulted on significant $(p \leq 0.05)$ improvements of tensile strength (Fig. 8d) and elongation at break (Fig. 8e) of the nanocomposites. For $6.5 \%$ of nanofibrils the increase was of around $24 \%$ for tensile strength and $51 \%$ for elongation at break in relation to control blend. Tensile modulus decreased significantly (around $40 \%$ ) in relation to the control blend (Fig. $8 \mathrm{f}$ ).

The lower performance of the nanocomposites with nanofibrils obtained with 5 passages in relation to 30 passages is probably because the former presents some agglomeration of nanofibrils that may cause fissures and/or cracks in the microstructure of the nanocomposites. On the other hand, for nanocomposites reinforced with nanofibrils from 30 passages through the defibrillator, the large surface area of the smaller nanofibrils permitted greater efficiency in the load transference from the matrix to the nanofibrils (Bilbao-Sainz et al., 2011). The improved distribution of the nanofibrils led to more efficient packaging and compact structure. Similar results were found elsewhere (Petersson et al., 2007; Lu et al., 2008; Jonoobi et al., 2010; Xu et al., 2013).

The values of tensile strength obtained in the present work are similar to those of linear low density polyethylene - LLDPE (37 MPa), polycaprolactone - PCL (20.7-42 MPa), and polypropylene - PP (35 MPa); and higher than values presented by low density polyethylene - LDPE (6.9-16.0 MPa), polyesteramide - PEA (17 MPa) and highly branched LDPE (8.5-10.5 MPa); which are polymers frequently used in flexible packages for food industry and agricultural sector (Doak, 1986; Averous, 2004; Auras et al., 2004).

\subsubsection{Morphology of the blend and nanocomposite surfaces}

SEM analyses permits visualize the homogeneity of the surface microstructure, including the presence of fissures, cracks and delaminations that may affect mechanical and barrier properties of the material. Fig. 9a and b present SEM micrographs of the control blend, which presented continuous and cohesive surface. No separations of the polymer phases (starch and PVA) were observed, demonstrating good interactions between them. Previous studies (Frost et al., 2011; Han et al., 2009; Tudorachi et al., 2000) also showed good compatibility between cassava starch and PVA due to the high presence of hydrogen bonding energy in both polymers.

Nanocomposites with $0.5 \%$ nanofibrils obtained after 5 passages presented some cracks and erupted bubbles (Fig. 9c). Similar results were reported by Jayasekara et al. (2004) and RindlavWestling et al. (2002), whose fissures may have been caused by surface wrinkling due to the drying process or differences in the drying shrinkage related to the presence of the nanofibrils and agglomerates. Specimens with 1.5 and $6.5 \%$ of nanofibrils obtained with 5 passages also presented great roughness due to the formation of agglomerates/clusters of nanofibrils (Fig. 9d and f). Among all nanocomposites reinforced with nanofibrils obtained with 5 passages, those with $4.5 \%$ concentration presented the best distribution within the blend matrix (Fig. 9e). It agrees with the higher average values of tensile strength (Fig. 8a) and elongation (Fig. 8b) for these nanocomposites in the previous section.

Fig. 10 depicts SEM micrographs of nanocomposites reinforced with nanofibrils obtained with 30 passages through the defibril- 

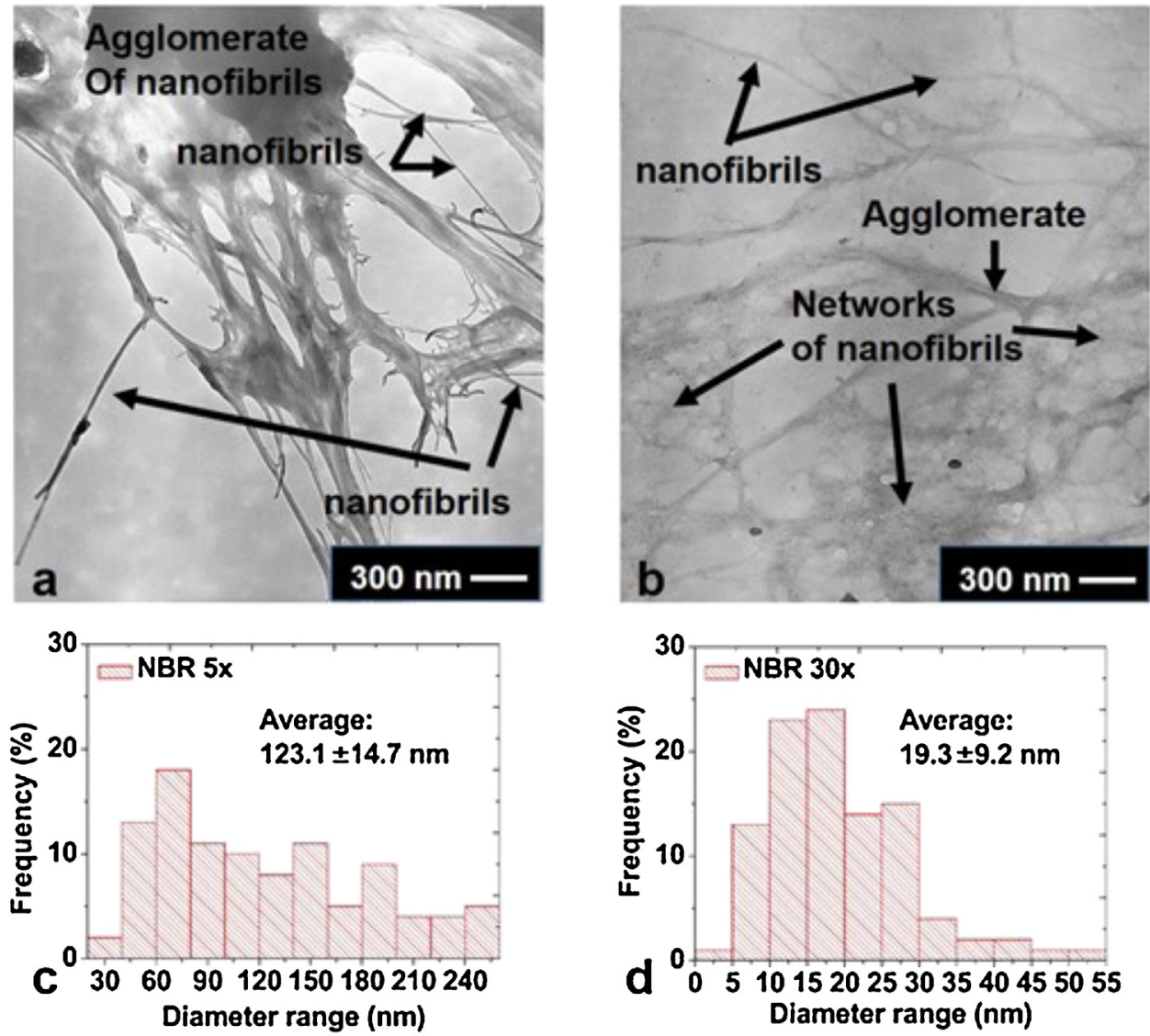

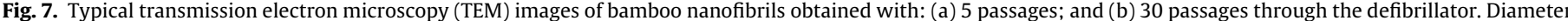
distribution (determined from measurements in the TEM images) of the bamboo nanofibrils: (c) 5 passages; and (d) 30 passages.
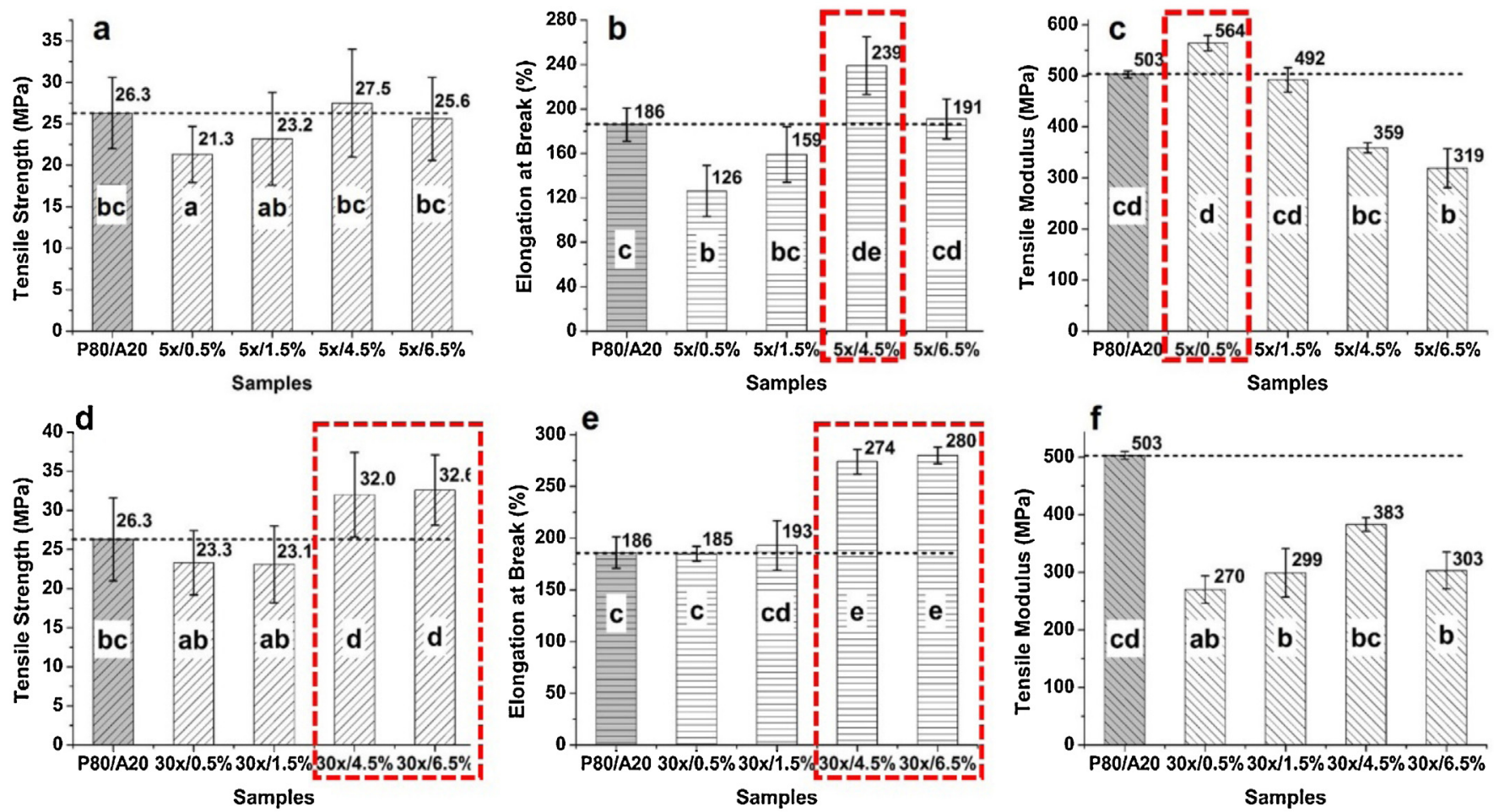

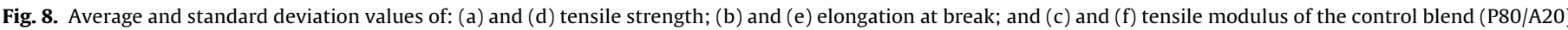

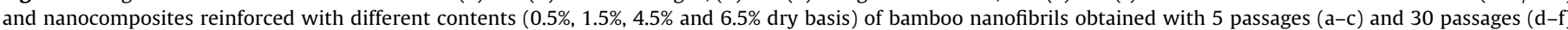

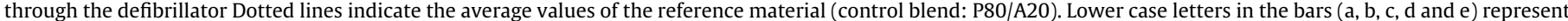
statistical comparisons using Fisher's test, while different letters indicate significant $(p \leq 0.05)$ differences between the films. 


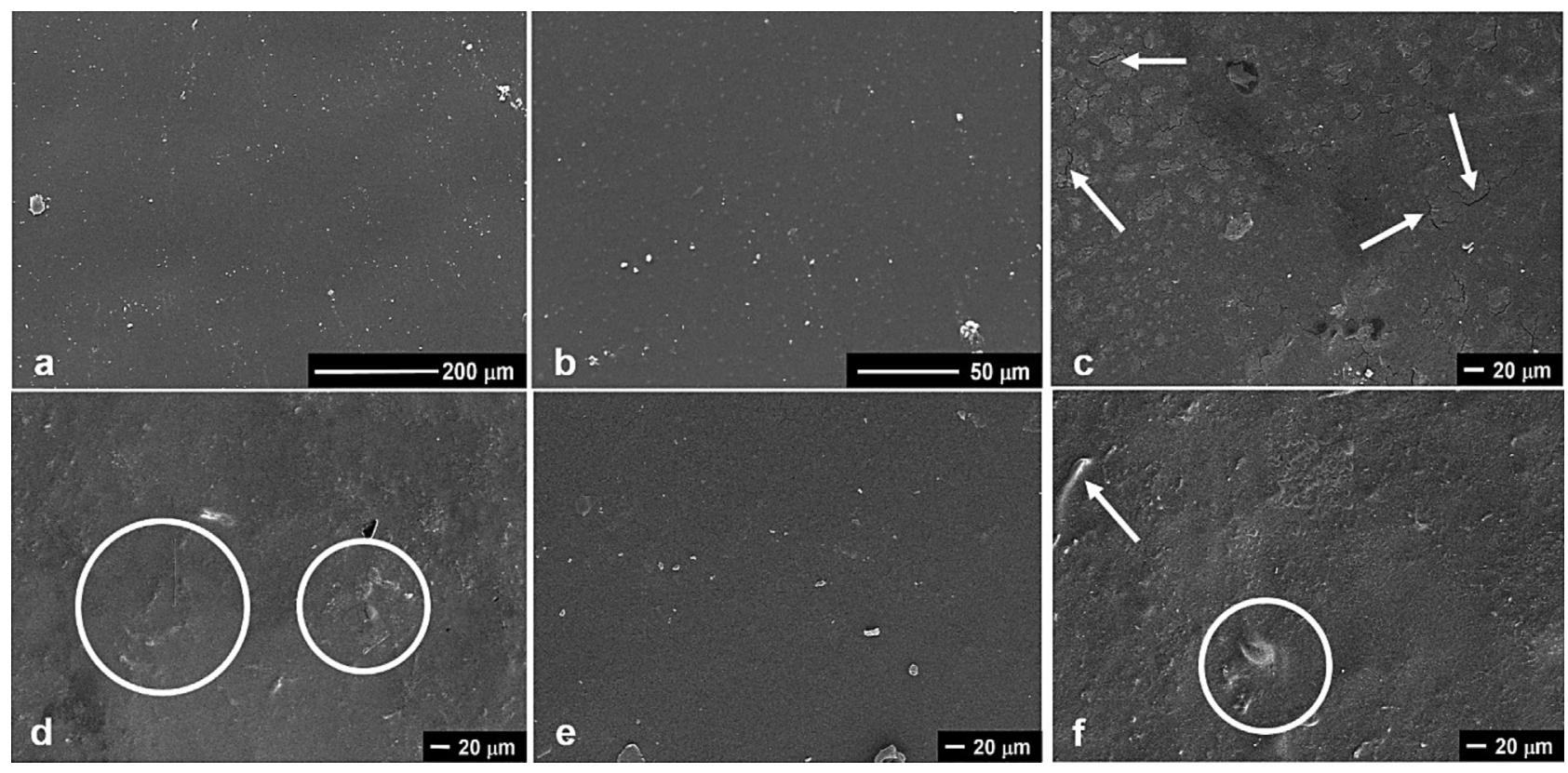

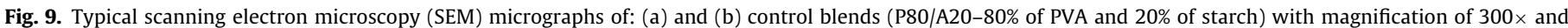

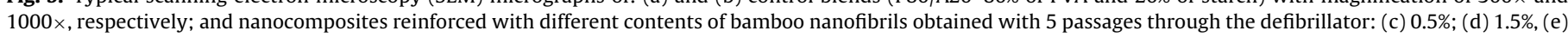
$4.5 \%$ and (f) $6.5 \%$, with magnification of $500 \times$. Arrows and circles indicate fissures and the formation of clusters.

lator. In this case nanofibrils are better dispersed in the matrix for all concentrations. The more compact surface, the cohesiveness, the homogeneity of the film, the absence of phase separation and minimum presence of bubbles, clusters and fissures are good evidences of the improved microstructure of this nanocomposites (Mali et al., 2004). As reported in the previous section, with 30 passages through the defibrillator, the nanofibrils showed a better interaction with the blend matrix due to the reduction of nanofibril
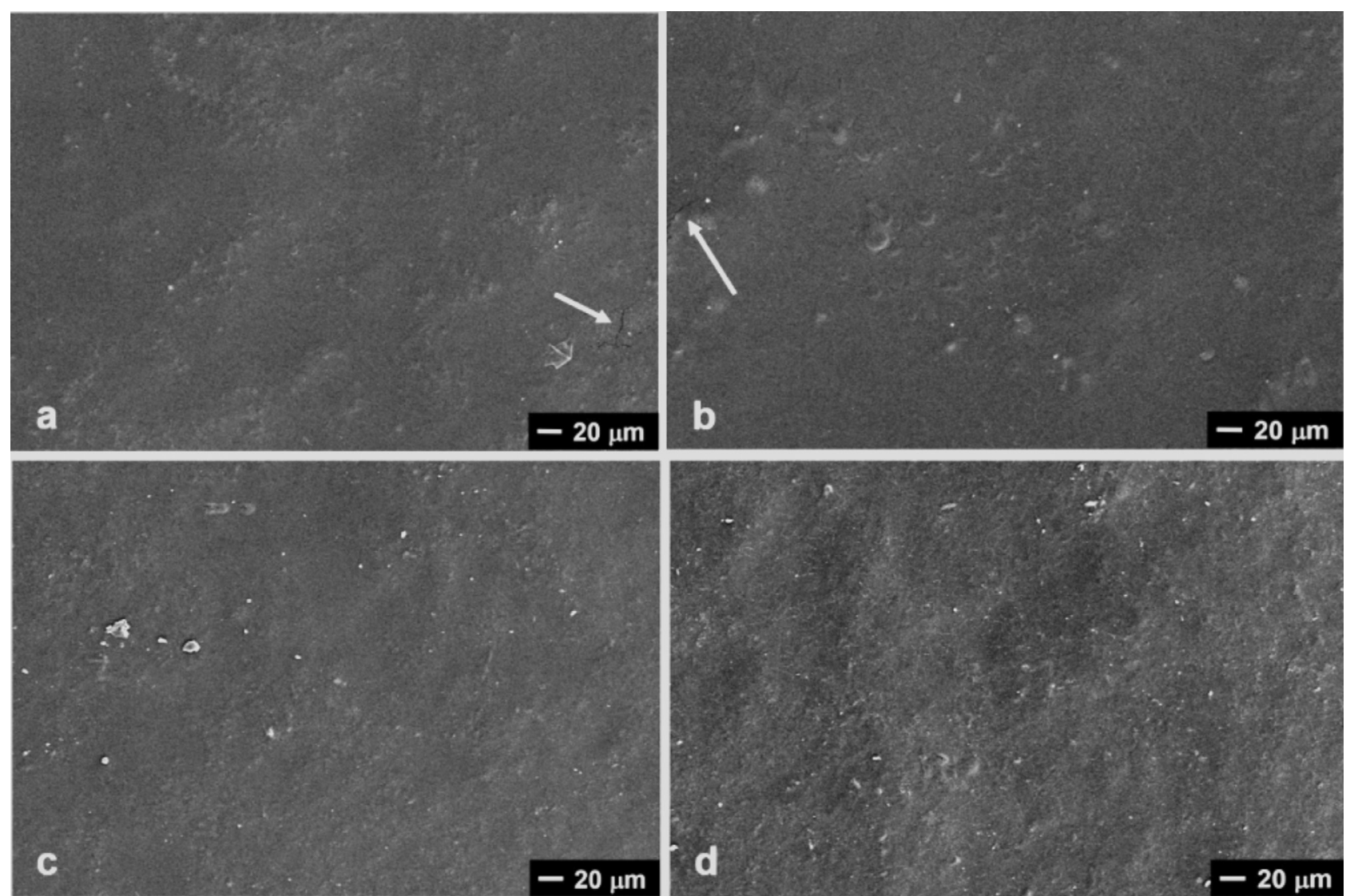

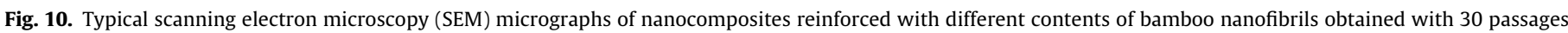
through the defibrillator: (a) 0.5\%; (b) 1.5\%; (c) 4.5\%; and (d) 6.5\%. Arrows show fissures. Magnification: 500×. 

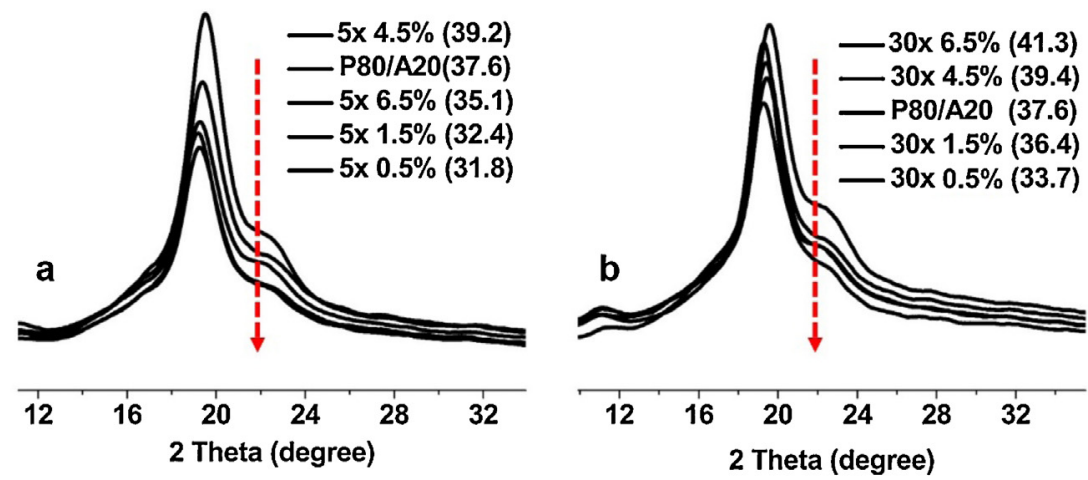

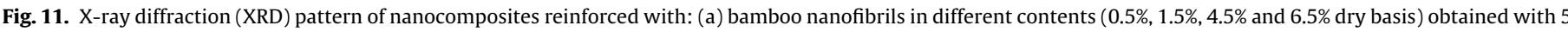

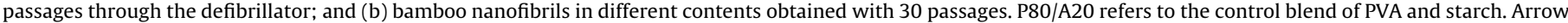
indicates the order of the samples (as presented in the legends), while values in parentheses are the calculated crystalline indexes of the films.

diameter that improves surface contact and increase free hydroxyls groups for bonding. Again, this result is consistent with the mechanical performance.

\subsection{3. $X$-ray diffractometry - DRX}

In general, starch presents some crystalline structure attributed to well organized amylopectin molecules (Moorthy, 2002). PVA is typically semicrystalline with an amorphous band and some degree of crystallinity depending on its degree of hydrolysis (Bassner and Klingenberg, 1998). Fig. 11 shows the characteristic diffraction peak of PVA at 2 Theta $=19.6^{\circ}$ (Das et al., 2010), and a shoulder at around 2 Theta $=22.5^{\circ}$, which is assigned to the (002) lattice plane of cellulose I in bamboo nanofibrils and to the crystal structures of the starch. Fig. 11b shows that bamboo nanofibrils obtained with 30 passages increased the crystallinity index of the nanocomposites in relation to those reinforced with nanofibrils obtained with 5 passages (Fig. 11a). This is because well-dispersed nanofibrils probably acted as nucleating agents for the crystals (Fujisawa et al., 2014; Wang et al., 2014).

\subsubsection{Physical properties}

3.3.4.1. Optical transmittance (Tr). Fig. 12 shows the $\operatorname{Tr}$ curves for the blend and nanocomposites. Blends are more transparent ( $\mathrm{Tr}=85 \%$ at $800 \mathrm{~nm}$ wavelength) than nanocomposites. Nanocomposites reinforced with bamboo nanofibrils obtained with 30 passages presented higher values of transmittance ( $\operatorname{Tr}$ between $79 \%$ and $84 \%$ at $800 \mathrm{~nm}$ wavelength) in relation to 5 passages, for all contents of nanofibrils (Fig. 12b). This is because nanofibrils from 30 passages are well dispersed and presents lower diameters, improving transparency of the films. Nanocomposites reinforced with nanofibrils from 5 passages (Fig. 12a) presented lower transmittance values ( $\operatorname{~r}$ from $60 \%$ to $78 \%$ ) probably due to the nanofibrils with high diameters and occasionally due to the poor dispersion of them.

Nanocomposites became more opaque as the concentration of nanofibrils increased for both passage numbers ( $5 x$ and $30 x$ ), because of the formation of a percolated web and some nanofibril clusters that block the transmittance of the light. The SEM images corroborate this discussion (Figs. 9c-f and Fig. 10a-d). Similar results were presented elsewhere (Bilbao-Sainz et al., 2011; Savadekar and Mhaske, 2012; Iwamoto et al., 2005; Bielecki et al., 2005; Chávez-Pacheco et al., 2004). The optical properties are an important issue for packaging films, because may influence the appearance of the products. Normally, a transparent packaging is desirable in order to allow of viewing the packed product (Brawn, 1992). In other cases, it is necessary to protect the product from light in order to reduce catalyzed deteriorations (Sarantópoulos et al., 2002).

3.3.4.2. Water vapor permeability (WVP). The average values of water vapor transmission rate (WVTR) and water vapor permeability (WVP) for nanocomposites reinforced with nanofibrils obtained with 5 and 30 passages are presented in Table 1. Lower contents $(0.5 \%$ and $1.5 \%)$ of nanofibrils led to some increase of WVTR and WVP probably because they are not enough to form a consistent network of nanofibrils capable of retain the penetration of water vapor. Instead, this low content of nanofibrils forms clusters and some porosity that causes a negative effect on barrier properties (Sanchez-Garcia et al., 2007). SEM images presented in previous sections (Fig. 9c-d and Fig. 10a-b) corroborate with
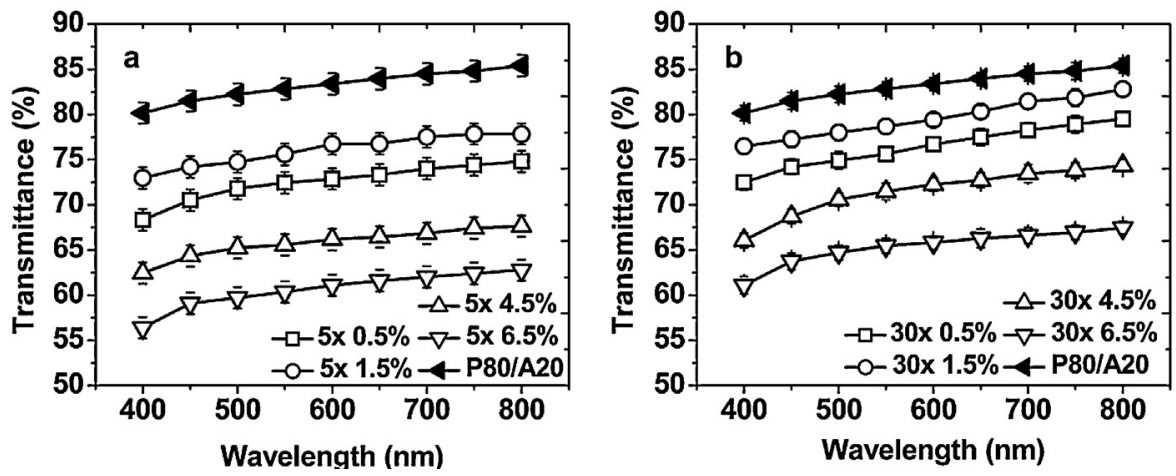

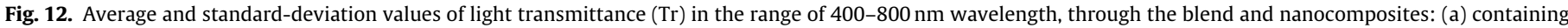

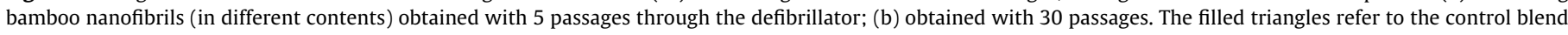
(P80/A20, composed of $80 \%$ PVA and $20 \%$ cassava starch). 
Table 1

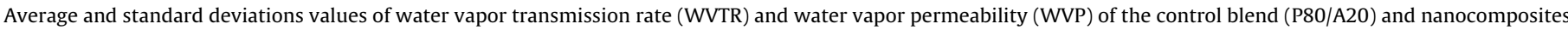
reinforced with different concentrations of bamboo nanofibrils obtained with 5 and 30 passages through the defibrillator.

\begin{tabular}{|c|c|c|c|c|}
\hline Material & Nanofibrils ${ }^{\mathrm{a}}(\%)$ & Thickness $^{\mathrm{b}}$ (mm) & WVTR $^{\mathrm{c}}\left(\mathrm{gH}_{2} \mathrm{O} / \mathrm{m}^{2}\right.$ day $)$ & $\mathrm{WVP}^{\mathrm{c}}\left(\mathrm{g} \mathrm{mm} / \mathrm{KPa}\right.$ day $\left.\mathrm{m}^{2}\right)$ \\
\hline Nanocomposite with & 0.5 & $0.085 \pm 0.009$ & $33.68 \pm 0.61$ & $1.31 \pm 0.02 \mathrm{~d}$ \\
\hline nanofibrils from 5 & 1.5 & $0.099 \pm 0.007$ & $30.34 \pm 0.95$ & $1.26 \pm 0.01 \mathrm{c}$ \\
\hline \multirow[t]{2}{*}{ passages } & 4.5 & $0.143 \pm 0.012$ & $24.60 \pm 0.97$ & $1.07 \pm 0.02 \mathrm{a}$ \\
\hline & 6.5 & $0.118 \pm 0.011$ & $27.16 \pm 1.57$ & $1.16 \pm 0.03 b$ \\
\hline Nanocomposite with & 0.5 & $0.081 \pm 0.006$ & $31.54 \pm 0.64$ & $1.25 \pm 0.02 b$ \\
\hline nanofibrils from 30 & 1.5 & $0.099 \pm 0.008$ & $29.82 \pm 1.18$ & $1.23 \pm 0.01 \mathrm{~b}$ \\
\hline \multirow[t]{2}{*}{ passages } & 4.5 & $0.127 \pm 0.011$ & $21.16 \pm 0.44$ & $0.98 \pm 0.03 \mathrm{a}$ \\
\hline & 6.5 & $0.105 \pm 0.009$ & $20.67 \pm 1.09$ & $0.94 \pm 0.02 \mathrm{a}$ \\
\hline Control blend (P80/A20) & - & $0.077 \pm 0.002$ & $29.13 \pm 0.22$ & $1.18 \pm 0.01 b$ \\
\hline
\end{tabular}

a Content indry weight.

b Average of 10 measurements.

c Average of 3 measurements.

d Blend composed of $80 \%$ PVA and 20\% cassava starch. Lower case letters (a-d)in the SOL column represent statistical comparisons using Scott-Knott test, while different letters indicate significant $(p \leq 0.05)$ differences between the values.

Table 2

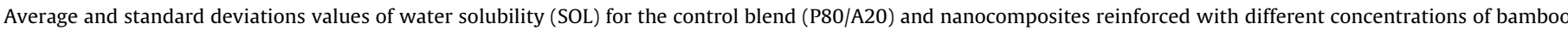
nanofibrils obtained with 5 and 30 passages through the defibrillator.

\begin{tabular}{|c|c|c|c|}
\hline Material & Nanofibrils ${ }^{\mathrm{a}}(\%)$ & Thickness $^{\mathrm{b}}(\mathrm{mm})$ & $\mathrm{SOL}^{\mathrm{C}}(\%)$ \\
\hline $\begin{array}{l}\text { Nanocomposite with } \\
\text { nanofibrils from } 5 \\
\text { passages }\end{array}$ & $\begin{array}{l}0.5 \\
1.5 \\
4.5 \\
6.5\end{array}$ & $\begin{array}{l}0.0803 \pm 0.012 \\
0.0887 \pm 0.011 \\
0.1231 \pm 0.012 \\
0.1064 \pm 0.014\end{array}$ & $\begin{array}{l}30.08 \pm 8.4 c \\
28.33 \pm 9.7 b \\
25.82 \pm 10.8 a \\
25.66 \pm 9.8 a\end{array}$ \\
\hline $\begin{array}{l}\text { Nanocomposite with } \\
\text { nanofibrils from } 30 \\
\text { passages }\end{array}$ & $\begin{array}{l}0.5 \\
1.5 \\
4.5 \\
6.5\end{array}$ & $\begin{array}{l}0.0776 \pm 0.009 \\
0.0883 \pm 0.012 \\
0.1131 \pm 0.009 \\
0.1077 \pm 0.011\end{array}$ & $\begin{array}{l}28.54 \pm 7.7 \mathrm{~d} \\
25.82 \pm 9.1 \mathrm{c} \\
21.16 \pm 7.7 \mathrm{~b} \\
17.33 \pm 9.1 \mathrm{a}\end{array}$ \\
\hline Control blend (P80/A20) $)^{d}$ & - & $0.0682 \pm 0.004$ & $25.47 \pm 4.6 c$ \\
\hline
\end{tabular}

a Content in dry weight.

b Average of 10 measurements.

c Average of 3 measurements.

d Blend composed of $80 \%$ PVA and 20\% cassava starch. Lower case letters (a-d)in the SOL column represent statistical comparisons using Scott-Knott test, while different letters indicate significant $(p \leq 0.05)$ differences between the values.

this results, showing the formation of pores, and fissures/cracks on those nanocomposite surfaces.

Addition of high contents of nanofibrils (4.5\% and 6.5\%) from 5 and 30 passages decreased the WVTR and WVP values of the nanocomposites in relation to the control blend (P80/A20). This decrease in permeability may be explained by the percolated network formed by the nanofibers, leading to a continuous network of hydrogen bonds that reduces the diffusion of water vapor (Sreekala et al., 2008; Lai and Padua, 1998; Kaushik et al., 2010). Similar behavior was found elsewhere (Mikkonen et al., 2011; Svagan et al., 2009; Dufresne et al., 2000). The values of WVTR Observed in the present work (20-30 g $/ \mathrm{m}^{2}$.day) are higher than values found for some to polymers used in the packaging sector (low-density polyethylene - $\mathrm{LDPE}=3.7 \mathrm{~g} / \mathrm{m}^{2}$.day, high-density polyethylene $\mathrm{HDPE}=3.5 \mathrm{~g} / \mathrm{m}^{2}$.day $)$ and polylactic acid - = PLA (12.6 g/ $/ \mathrm{m}^{2}$.day) (Petersen et al., 2001).

3.3.4.3. Water solubility (SOL). The control blend and all nanocomposites evaluated became opaque after $24 \mathrm{~h}$ immersed in water, while continuing flexible and foldable. Water solubility was significantly higher $(p>0.05)$ for nanocomposites with $0.5 \%$ nanofibrils (in both number of passages) (Table 2 ). Water solubility was around $30 \%$ lower (in comparison to the control blend) for nanocomposites reinforced with $6.5 \%$ of nanofibrils obtained with 30 passages through the defibrillator. As discussed before, this result is consequence of the lower diameters of the nanofibrils produced in this condition, which improved the percolated network (Müller et al., 2009) and decreased pores and fissures in these nanocomposites. In contrast, the formation of fissures and pores occurred in specimens with fibril agglomerations or insufficient amount of nanofibrils bonded together. Results of water solubility agree with the findings for vapor permeability.

\section{Conclusions}

Bamboo nanofibrils were effectively isolated from commercial refined bamboo pulp. Chemical pre-treatments (alkaline and bleaching) were used to improve the individualization of the nanofibrils in the mechanical defibrillator. Morphological analysis using atomic force microscopy (AFM) indicated a reduction of around $88 \%$ (from $82 \pm 29 \mathrm{~nm}$ to $10 \pm 6 \mathrm{~nm}$ ) in the average diameter of the nanofibrils obtained with 30 passages through the defibrillator, which made the nanofibril suspensions more stable in relation to 5 passages. Tensile strength and elongation at breaking of the nanocomposite films were increased in up to 24 and $51 \%$, respectively, for the high contents (4.5 and 6.5) of nanofibrils compared to the control blend. Light transmission of the nanocomposite films were better for nanofibrils obtained with 30 passages, and decreased with the increase on the nanofibril content. Results showed that the higher contents $(4.5 \%$ and $6.5 \%$ ) of nanofibrils reduced up to 20 and $30 \%$ the values of water vapor permeability and water solubility, respectively, in relation to the control blend. The present work demonstrates the feasibility of producing bamboo nanofibrils (by mechanical defibrillation) that can be used as reinforcement to engineer polymeric nanocomposites for a myriad of applications. 


\section{Acknowledgments}

Authors thank to Fundação de Amparo à Pesquisa do Estado de Minas Gerais (FAPEMIG), Fundação de Amparo à Pesquisa do Estado de São Paulo (FAPESP), Coordenação de Aperfeiçoamento de Pessoal de Nível Superior (CAPES) and Conselho Nacional de Desenvolvimento Científico e Tecnológico (CNPq). Thanks also to Centro Federal de Educação Tecnológica de Minas Gerais (CEFETMG), Rede Temática de Engenharia de Materiais (REDEMAT) and Rede Brasileira de Compósitos e Nanocompósitos Lignocelulósicos (RELIGAR), in Brazil. Thanks also to Instituto de Tecnologia de Alimentos/Centro de Tecnologia de Embalagem (ITAL/CETEA), PGCTM (UFLA), LME (UFLA), DCF (UFLA) and DCA (UFLA).

\section{References}

Abe, K., Yano, H., 2010. Comparison of the characteristics of cellulose microfibril aggregates isolated from fiber and parenchyma cells of Moso bamboo (Phyllostachys pubescens). Cellulose 17, 271-277, http://dx.doi.org/10.1007/s10570-009-9382-1.

American Society for Testing and Materials, 2000. Standard test methods for tensile properties of thin plastic sheeting, In: ASTM d882-00, Philadelphia.

American Society for Testing and Materials, 2000. Standard test methods for water vapor transmission of materials In: ASTM e96-00, Philadelphia.

Auras, R., Harte, B., Selke, S., 2004. An overview of polylactides as packaging materials. Macormol. Biosci. 4, 835-864.

Averous, L., 2004. Biodegradable multiphase system based on plasticized starch: a review. J. Macromol. Sci. Part C-Polym. Rev. 44, 231-274.

Averous, L., Boquillon, N., 2004. Biocomposites based on plasticized starch: thermal and mechanical behaviours. Carbohydr. Polym. 56, 111-122.

Samir, Azizi., Alloin, M.A., F, Dufresne, A., 2005. Review of recent research into cellulosic whiskers their properties and their application in nanocomposite field. Biomacromolecules 6, 612-626, http://dx.doi.org/10.1021/bm0493685.

Bassner, S.L., Klingenberg, E.H., 1998. Using poly(vinyl alcohol) as a binder. Am. Ceram. Soc. Bull. 77, 71-75.

Beliakova, M.K., Aly, A.A., Abdel-Mohdy, F.A., 2004. Grafting of poly(methacrylic acid) on starch and poly(vinyl alcohol). Starch-Stärke 56, 407-412.

Bielecki, S., Krystynowicz, A., Turkiewicz, M., Kalinowska, H., 2005. Bacterial cellulose. Biopolym. Online 14, 381, http://dx.doi.org/10.1002/3527600035.bpol5003.

Bilbao-Sainz, C., Bras, J., Williams, T., Sénechal, T., Orts, W., 2011. HPMC reinforced with different cellulose nano-particles. Carbohydr. Polym. 86, 1549-1557, http://dx.doi.org/10.1016/j.carbpol.2011.06.060.

Brawn, W.E., 1992. Plastics in Food Packaging Properties, Design and Fabrication, 8-10. Marcel Dekker Inc., New York, pp. 539.

Bufalino, L., Mendes, L.M., Tonoli, G.H.D., Rodrigues, A., Fonseca, A.S., Cunha, P.I, Marconcini, J.M., 2014. New products made with lignocellulosic nanofibers from Brazilian amazon forest. IOP Conf. Ser. Mater. Sci. Eng. 64, 012012 , http://dx.doi.org/10.1088/1757-899X/64/1/012012.

Chang, P.R., Jian, R., Yu, J., Ma, X., 2010. Starch-based composites reinforced with novel chitin nanoparticles. Carbohydr. Polym. 80, 421-426.

Chávez-Pacheco, J.L., Yee, S.M., Zentella, M.C., Marván, E.E., 2004. Celulosa bacteriana en gluconacetobacter xylinum: biosíntesis y aplicaciones. Rev. Especial. Cienc Quím-Biol. 7, 18-25.

Chen, H.Z., Chen, J.Z., Liu, J., Li, Z.H., 1999. Studies on the steam explosion of wheat straw: effects of the processing conditions for steam explosion of wheat straw and analysis of the process. J. Cellul. Sci. Technol. 7, 60-67.

Chen, Y., Cao, X., Chang, P.R., Huneault, M.A., 2008. Comparative study on the films of poly(vinyl alcohol)/pea starch nanocrystals and poly(vinyl alcohol)/native pea starch. Carbohydr. Polym. 73, 8-17, http://dx.doi.org/10.1016/j.carbpol.2007.10.015.

Cinelli, P., Chiellini, E., Lawton, J.W., Imam, S.H., 2006. Foamed articles based on potato starch corn fibers and poly(vinyl alcohol). Polym. Degrad. Stab. 91, 1147-1155.

Corradini, E., Morais, L.C., Rosa, M.F., Mazzetto, S.E., Mattoso, L.H., Agnelli, J.A.M.A. 2006. Preliminar study for the use of material natural fibres as reinforcement in starch-gluten-glycerol matrix. Macromol. Symp. 245-246, 558-564.

Das, K., Ray, D., Bandyopadhyay, N.R., Gupta, A., Sengupta, S., Sahoo, S., 2010. Preparation and characterization of croos-linked starch/poly(vinyl alcohol) green films with low moisture absorption. Ind. Eng. Chem. Res. 49, 2176-2185, http://dx.doi.org/10.1021/ie901092n.

Dinand, E., Chanzy, H., Vignon, M.R., 1999. Suspensions of cellulose microfibrils from sugar beet pulp. Food Hydrcolloids 13, 275-283, http://dx.doi.org/10.1016/S0268-005X(98)00084-8.

Doak, K.W., 1986. Ethylene Polymers. In: Mark, H.M., Bilakes, N.M., Overberg, C.G., Mendes, G. (Eds.), Encyclopedia of Polymer Science and Engineering, 6. John-Wiley \& Sons, New York.

Dufresne, A., Cavaille, J.Y., Vignon, M.R., 1997. Mechanical behavior of sheets prepared from sugar beet cellulose microfibrils. J. Appl. Polym. Sci. 64 1185-1194.
Dufresne, A., Dupeyre, D., Vignon, M.R., 2000. Cellulose microfibrils from potato tuber cells: processing and characterization of starch-cellulose microfibril composites. J. Appl. Polym. Sci. 76, 2080-2092,

http://dx.doi.org/10.1002/(SICI)1097-4628(20000628)76:14<2080::AID-APP12>3.0.CO;2-U-

Flauzino Neto, W.P., Silvério, H.A., Dantas, N.O., Pasquini, D., 2013. Extraction and characterization of cellulose nanocrystals from agro- industrial residue-Soy hulls. Ind. Crops Prod. 42, 480-488,

http://dx.doi.org/10.1016/j.indcrop.2012.06.041.

Follain, N., Joly, C., Dole, P., Bliard, C., 2005. Mechanical properties of starch-based materials: I. short review and complementary experimental analysis. J. Appl. Polym. Sci. 97, 1783-1794.

Frost, K., Barthes, J., Kaminski, D., Lascaris, E., Niere, J., Shanks, R., 2011. Thermoplastic starch-silica-polyvinyl alcohol composites by reactive extrusion. Carbohydr. Polym. 84, 343-350.

Fujisawa, S., Zhang, J., Saito, T., Iwata, T., Isogai, A., 2014. Cellulose nanofibibrils as templates for the design of poly(L-lactide) nucleating surfaces. Polymer 55, 2937-2942.

Gomide, J.L., 1986. Estudo sobre a constituição química do Bambusa vulgaris, visando a produção de polpa celulósica. O Papel 47, 64-68.

Gomide, J.L., Colodette, J.L., Oliveira, R.C., 1982. Estudo das possibilidades do Bambusa vulgaris para produção de papéis tipo kraft. O Papel 28, 38-42.

Gontard, N., Duchez, C., Cuq, J.L., Guilbert, S., 1994. Edible composite films of wheat gluten and lipids: water vapour permeability and other physical properties. Int. J. Food Sci. Technol. 29, 39-50, http://dx.doi.org/10.1111/j.1365-2621.1994.tb02045.x.

Guimarães Junior, M., Botaro, V.R., Novack, K.M., Flauzino Neto, W.P., Mendes, L.M., Tonoli, G.H.D., 2015. Preparation of cellulose nanofibrils from bamboo pulp by mechanical defibrillation for their applications in biodegradable composites. J. Nanosci. Nanotechnol. 15, http://dx.doi.org/10.1166/jnn.2015.10854 (in press).

Han, X.Z., Chen, S.S., Hu, X.G., 2009. Controlled-release fertilizer encapsulated by starch/polyvinyl alcohol coating. Desalination 240, 21-26.

Ifuku, S., Nogi, M., Yoshioka, M., Morimoto, M., Yano, H., 2010. Fibrillation of dried chitin into $10-20 \mathrm{~nm}$ nanofibers by a simple grinding method under acidic condition. Carbohydr. Polym. 81, 134-139.

Ishiaku, U.S., Pang, K.W., Lee, W.S., Ishak, Z.A., 2002. Mechanical properties and enzymic degradation of thermoplastic and granular sago starch filled poly(caprolactone). Eur. Polym. J. 38, 393-401.

Iwamoto, S., Nakagaito, A.N., Yano, H., Nogi, M., 2005. Optically transparent composites reinforced with plant fiber-based nanofibers. Appl. Phys. A 81, 1109-1112, http://dx.doi.org/10.1007/s00339-005-3316-z.

Jayasekara, R., Harding, I., Bowater, I., Christie, G.B.Y., Lonergan, G.T., 2004. Preparation, surface modification and characterisation of solution cast starch PVA blended films. Polym. Test. 23, 17-27.

Jonoobi, M., Harun, J., Mathew, A.P., Oksman, K., 2010. Mechanical properties of cellulose nanofiber (CNF) reinforced polylactic acid (PLA) prepared by twin screw extrusion. Compos. Sci. Technol. 70, 1742-1747.

A. Kaboorani, B. Riedl, In: Blanchet quest editor. Pierre: Felin M, Hosseinaei O, Wang S. Nanocrystalline celulose (NCC): a renewable nano-material for polyvinyl acetate (PVA) adhesive, Euro Polym J 48 2012; 1829-1837.

Kampeerapappun, P., Aht-Ong, D., Pentrakoon, D., Srikulkit, K., 2007. Preparation of cassava starch/montmorillonite composite film. Carbohydr. Polym. 67, 155-163, http://dx.doi.org/10.1016/j.carbpol.2006.05.012.

Karimi, S., Tahir, P., Karimi, A., Dufresne, A. Abdulkhani, A, 2014. Kenaf bast cellulosic fibers hierarchy: a comprehensive approach from micro to nano. Carbohydr. Polym. 101, 878-885.

Kaushik, A., Singh, M., Verma, G., 2010. Green nanocomposites based on thermoplastic starch and steam exploded cellulose nanofibrils from wheat straw. Carbohydr. Polym. 82, 337-345, http://dx.doi.org/10.1016/j.carbpol.2010.04.063.

Khan, M.A., Bhattacharia, S.K., Kader, M.A., Bahari, K., 2006. Preparation and characterization of ultra violet (UV) radiation cured bio-degradable films of sago starch/PVA blend. Carbohydr. Polym. 63, 500-506.

Kvien, L., Tanem, B.S., Oksman, K., 2005. Characterization of cellulose whiskers and their nanocomposites by atomic force and electron microscopy. Biomacromolecules 6, 3160-3165, http://dx.doi.org/10.1021/bm050479t.

Lai, H.M., Padua, G.W., 1998. Water vapor barrier properties of zein films plasticized with oleic acid. Cereal Chem. 75, 194-199, http://dx.doi.org/10.1094/CCHEM.1998.75.2.194.

Lawton, J.W., 1996. Effect of starch type on the properties of starch containing films. Carbohydr. Polym. 29, 203-208.

Li, M., Wang, L.J., Li, D., Cheng, Y.L., Adhikar, B., 2014. Preparation and characterization of cellulose nanofibers fromde-pectinated sugar beet pulp. Carbohydr. Polym. 102, 1346-1403.

Li, X.B., Shape, T.F., Peter, G.F., Hse, C.Y., Eberhardt, T.L., 2007. Chemical changes with maturation of the bamboo species Phyllostachys pubescens. J. Trop. Forest Sci. 19, 6-12.

Lu, J., Wang, T., Drzal, L.T., 2008. Preparation and properties of microfibrillated cellulose polyvinyl alcohol composite materials. Compos. Part A Appl. Sci. Manuf. 39, 738-746, http://dx.doi.org/10.1016/j.compositesa.2008.02.003.

Mali, S., Karam, L.B.R., Ramos, L.P., Grossmann, M.V.E., 2004. Relationships among the composition and physicochemical properties of starches with the characteristics of their films. J. Agric. Food Chem. 52, 7720-7725, http://dx.doi.org/10.1021/jf049225+.

Mikkonen, K.S., Stevanic, J.S., Joly, C., Dole, P., Pirkkalainen, K., Serimaa, R., 2011. Composite films from spruce galactoglucomannans with microfibrillated spruce wood cellulose. Cellulose 18, 713-726. 
Mohanty, A.K., Misra, M., Hinrichsen, G., 2000. Biofibres, biodegradable, polymer and composites: an overview. Macromol. Mater. Eng. 276-277, 1-24.

Moorthy, S.N., 2002. Physicochemical and functional properties of tropical tuber starches: a review. Starch-Stärke 54, 559-592 http://dx.doi.org/10.1002/1521-379X(200212)54:12<559::AID-STAR2222559>3.0.

R.L.C. Morais M. Benachour A.C. Duarte-Coelho Estudo da caracterização reológica do licor negro do processo soda/Bambusa vulgaris Schrad e o efeito da adição de peróxido de hidrogênio In: Congresso Iberoamericano de Investigación em celulosa y papel 2000 .

Müller, C.M.O., Laurindo, J.B., Yamashita, F., 2009. Effect of cellulose fibers addition on the mechanical properties and water vapor barrier of starch-based films. Food Hydrocolloids 23, 1328-1333. http://dx.doi.org/10.1016/j.foodhyd.2008.09.002.

Mwaikambo, L.Y., 2006. Review of the history, properties and application of plant fibres. Afr. J. Sci. Technol. 7, 120-133.

Nabar, Y.U., Draybuck, D., Narayan, R., 2006. Physicomechanical and hydrophobic properties of starch foams extruded with different biodegradable polymers. J. Appl. Polym. Sci. 102, 58-68.

Nakagaito, A.N., Yano, H., 2004. The effect of morphological changes from pulp fiber towards nano-scale fibrillated cellulose on the mechanical properties of high-strength plant fiber based composites. Appl. Phys. A 78, 547-552.

Nguyen, X.T., Tan, Z., 2009. Surface treatment with texturized microcrystalline cellulose microfibrils for improved paper and paper board, Patent United States Patent, 7497924.

Okiyama, A., Motoki, M., Yamanaka, S., 1993. Bacterial cellulose IV. Application to processed foods. Food Hydrocolloids 6, 503-511, http://dx.doi.org/10.1016/S0268-005X(09)80074-X.

Olobarrieta, I., 2005. Satrategies to improve the aging, barrier and mechanical properties of chitosan whey and wheat gluten protein films. In: Tesis de doutorado. Department of Fibre and Polymer Technology. Royal Institute of Technology, Stockholm, Sweden.

Orts, W.J., Shey, J., Imam, S.H., Glenn, G.M., Guttman, M.E., Revol, J.F., 2005. Application of cellulose microfibrils in polymer nanocomposites. J. Polym. Environ. 13, 301-306, http://dx.doi.org/10.1007/s10924-005-5514-3.

Park, S.I., Zhao, Y., 2004. Incorporation of a high concentration of mineral or vitamin into chitosan-based films. J. Agric. Food Chem. 52, 1933-1939, http://dx.doi.org/10.1021/jf034612p.

A.L.S. Pereira, D.M. Nascimento, J.P.S. Morais, M.S.M. Souza Filho, M.F. Rosa, Valorização de resíduos agroindustriais: uso do pseudocaule de bananeira como matéria-prima para obtenção de nanoestruturas de celulose. In: Encontro de Iniciação Científica da Embrapa Agroindústria Tropical, 8., 2010. Fortaleza. Resumos. Fortaleza: Embrapa Agroindústria Tropical,

http://ainfo.cnptia.embrapa.br/digital/bitstream/item/34438/1/RE10163.pdf.< /span>.

Petersen, K., Nielsen, P.V., Olsen, M.B., 2001. Physical and mechanical properties of biobased materials-starch polylactate and polyhydroxybutyrate. Starch-Starke $53,356-361$

Petersson, L., Kvien, I., Oksman, K., 2007. Structure and thermal properties of poly(lactic acid)/cellulose whiskers nanocomposite materials. Compos. Sci. Technol. 67, 2535-2544.

Ramaraj, B., 2007. Crosslinked poly(vinyl alcohol) and starch composite films.II. Physicomechanical: thermal properties and swelling studies. J. Appl. Polym. Sci. 103, 909-916.

Rindlav-Westling, A., Stading, M., Gatenholm, P., 2002. Crystallinity and morphology in films of starch amylose and amylopectin blends. Biomacromolecules 3, 84-91, http://dx.doi.org/10.1021/bm010114i.

Sanchez-Garcia, M.D., Gimenez, E., Lagaron, J.M., 2007. Morphology and barrier properties of solvent cast composites of thermoplastic biopolymers and purified cellulose fibers. Carbohydr Polym 71, 235-244 http://dx.doi.org/10.1016/j.carbpol.2007.05.041.

Sarantópoulos, C.G.L., Oliveira, L.M., Padula, M., Coltro, L., Alves, R.M.V., Garcia, E.E.C., 2002. Embalagens plaísticas flexiíveis: principais poliímeros e avaliaça o de propriedades. Campinas: CETEA/ITAL 1, 267.

Savadekar, N.R., Mhaske, S.T., 2012. Synthesis of nano cellulose fibers and effect on thermoplastics starch based films. Carbohydr. Polym. 89, 146-151, http://dx.doi.org/10.1016/j.carbpol.2012.02.063.

Siddaramaiah, S., Raj, B., Somashekar, R., 2004. Structure-property relation in polyvinyl alcohol/starch composites. J. Appl. Polym. Sci. 91, 630-635.
Silvério, H.A., Flauzino Neto, W.P., Dantas, N.O., Pasquini, D., 2013. Extraction and characterization of cellulose nanocrystals from corncob for application as reinforcing agent in nanocomposites. Ind. Crops Prod. 44, 427-436.

Siqueira, G., Bras, J., Dufresne, A., 2010. Cellulosic bionanocomposites: a review of CO;2- p.reparation, properties and applications. Polymers 2, 728-765.

Siro, I., Plackett, D., 2010. Microfibrillated cellulose and new nanocomposite materials: a review. Cellulose 17, 459-494, http://dx.doi.org/10.1007/s10570-010-9405-y.

Sreedhar, B., Chattopadhyay, D.K., Karunakar, M.S.H., Sastry, A.R.K., 2006. Thermal and surface characterization of plasticized starch polyvinyl alcohol blends crosslinked with epichlorohydrin. J. Appl. Polym. Sci. 101, 25-34.

Sreekala, M.S., Goda, K., Devi, P.V., 2008. Sorption characteristics of water, oil and diesel in cellulose nanofiber reinforced corn starch resin/ramie fabric composites. Compos. Interfaces 15, 281-299.

Suess, H.U., 2010. Pulp Bleaching Today. De Gruyter.

Svagan, A.J., Hedenqvist, M.S., Berglund, L., 2009. Reduced water vapour sorption in cellulose nanocomposites with starch matrix. Compos. Sci. Technol. 69 500-506.

Syverud, K., Chinga-Carrasco, G., Toledo, J., Toledo, P.G., 2011. A comparative study of Eucalyptus and Pinus Radiata pulp fibres as raw materials for production of cellulose nanofibrils. Carbohydr. Polym. 84, 1033-1038, http://dx.doi.org/10.1016/j.carbpol.2010.12.066.

TAPPI Useful Method Technicall Association of the Pulp and Paper Industry, 1999a: preparation of wood for chemical analysis (Test Method T 264cm-97). Atlanta, USA.

TAPPI Useful Method Technicall Association of the Pulp and Paper 1999b: sampling and preparing wood for analysis (Test Method T 257cm-97). Atlanta, USA.

TAPPI Useful Method Technicall Association of the Pulp and Paper 1999c: Holocellulose in wood (Test Method T 9 m- 54). Atlanta, USA

TAPPI Useful Method Technicall Association of the Pulp and Paper 1999d: alpha, beta and gama cellulose in pulp (Test Method T 203cm-99). Atlanta, USA.

TAPPI Useful Method.Technicall Association of the Pulp and Paper 1999e: acid insoluble lignin in wood and pulp (Test Method T 222cm-88). 1999. Atlanta, USA.

TAPPI Useful Method Technicall Association of the Pulp and Paper 1999f: ash in wood, pulp, paper and paperboard: combustion at $525^{\circ} \mathrm{C}$ (Test Method T $211 \mathrm{~cm}-93)$. Atlanta, USA.

TAPPI Useful Method Technicall Association of the Pulp and Paper 1999g: solvent extractives of wood and pulp (Test Method T 204cm-97). Atlanta, USA

Tetens, V.O., 1930. Uber einige meteorologische. Begriffe. Z- Geophysik 6, 297-309.

Tonoli, G.H.D., Teixeira, E.M., Correa, A.C., Marconcini, J.M., Caixeta, L.A., Pereira-da-Silva, M.A., Mattoso, L.H.C., 2012. Cellulose micro/nanofibers from eucaliptus kraft pulp: preparation and properties. Carbohydr. Polym. 89, 80-88.

Tudorachi, N., Casaval, C.N., Rusu, M., Pruteanu, M., 2000. Testing of polyvinyl alcohol and starch mixtures as biodegradable polymeric materials. Polym. Test. 19, 785-799, http://dx.doi.org/10.1016/S0142-9418(99)00049-5.

Utracki, L.A., 1989. Polymer and Blends: Thermodynamics and Rheology, 1st ed. Hanser Publishers, New York.

Villanova, J.C.O., Ayres, E., Carvalho, S.M., Patrício, O.S., Pereira, F.V., Oréfice, R.L., 2011. Pharmaceutical acrylic beads obtained by suspension polymerization containing cellulose nanowhiskers as excipient for drug delivery. Eur. J. Pharm. Sci 42, 406-415, http://dx.doi.org/10.1016/j.ejps.2011.01.005.

Wahab, R., Mustafa, M.T., Salam, of four cultivated tropical bamboo in genus Gigantochloa. J. Agric. Sci. 5, 66-75, http://dx.doi.org/10.5539/jas.v5n8p66.

Wang, X., Sun, H., Bai, H., Zhang, L.P., 2014. Thermal, mechanical, and degradation properties of nanocomposites prepared using lignin-cellulose nanofibers and poly (lactic acid). BioResource 9, 3211-3224.

Xu, X., Liu, F., Jiang, L., Zhu, J.Y., Haagenson, D., Wiesenborn, D.P., 2013. Cellulose nanocrystals vs. cellulose nanofibrils: a comparative study on their microstructures and effects as polymer reinforcing agents. ACS Appl. Mater. Interfaces 5, 2999-3009, http://dx.doi.org/10.1021/am302624t.

Zhai, M.L., Yoshii, F., Kume, T., 2003. Radiation modification of starch-based plastic sheets. Carbohydr. Polym. 52, 311-317. 